\title{
Nutritional factors and immunological ageing
}

\author{
Bruno Lesourd \\ EA 2431, Faculté de Médecine, 28 Place Henri Dunant, 63001 Clermont-Ferrand and Hôpital Nord du CHU \\ de Clermont-Ferrand, BP 36, 63118 Cébazat, France
}

\begin{abstract}
Undernutrition profoundly affects immune responses, particularly at the extremities of life: in infants and in the elderly. The present review focuses on this interrelationship in the elderly. It describes three different stages of ageing: stage 1, healthy ageing, which is observed in very healthy elderly individuals who have no nutritional deficit; stage 2, common ageing, which is observed in most elderly individuals in whom various micronutrient deficits are found; stage 3 , pathological ageing, which is observed in patients with protein-energy deficiency. Stage 1, primary immune ageing, is essentially characterized by changes in T-cell subsets but no change in T-cell function; T-cell function is reduced only in the very elderly ( $>90$ years old). Stage 2 , secondary immune ageing, is influenced by micronutrient deficits that may be corrected by providing nutritional supplements. Furthermore, immune responses may also be enhanced by supplementation of subjects who have no micronutrient deficits, indicating that the immune system of elderly individuals is highly susceptible to the influence of micronutrients. In stage 3 , tertiary immune ageing, the immune responses are strongly related to the decreased nutritional status. In these patients decreased immune responses lead to long-lasting acute-phase responses, which induce greater use of nutritional reserves during disease and lead to increased frailty. As nutritional status has a marked effect on immune responses in elderly individuals, nutritional therapy should be given to elderly individuals who have nutrient deficits, and perhaps also to individuals who do not have nutrient deficits in order to promote healthy ageing and extend the lifespan.
\end{abstract}

Immune ageing: Nutritional ageing: Nutrition-immunity interactions

Ageing has been shown to induce decreases in the immune responses, mainly in cell-mediated immune (CMI) responses (Albright \& Albright, 1984; Miller, 1992), and also changes in humoral immunity, with lower levels of specific antibodies (Arreaza et al. 1993). However, more recent studies that have quantified immune responses in well-selected healthy elderly individuals have indicated that the decreased CMI responses are less important than was previously suggested (Mazari \& Lesourd, 1998; Ahluwalia et al. 2001). Indeed, very healthy elderly individuals aged $70-80$ years who have been very carefully selected using defined protocols for healthiness (Ligthart et al. 1984; Lesourd \& Mazari, 1999) have levels of lymphocyte proliferation and Il-2 release that are comparable with those of young controls aged 20-30 years (Lesourd \& Mazari, 1999; Lesourd et al. 2002) and no changes in CD3 + cells (Pawelec et al. 1997). CMI responses appear to be lowered only in very elderly healthy individuals (age $\geq 90$ years; Lesourd et al. 2002). These findings suggest that factors other than immune ageing have a major influence on the immune responses of elderly individuals and that different factors influence the ageing of the immune system.

Environmental factors, through antigen enhancement, permanently activate the immune system. There is consequently a state of permanent renewal within the immune system, with the daily production of millions of immune cells. Immune cell renewal is increased during all metabolic processes, not only during infections, but also during diseases such as cardiac diseases. As ageing is characterized by the presence of disease processes, it seems obvious that such processes, even at low levels that are not always clinically manifest, may influence immune ageing. In order to be efficient, permanent cell renewal needs appropriate nutrition. As a consequence all nutritional deficits can affect immune responses. Indeed, it has been shown that 
Table 1. Functions of peripheral blood lymphocytes, stimulated in vitro with purified phytohaemagglutinin (PHAp), in healthy young individuals and in healthy and frail young elderly and old elderly individualsł

(Values are means and standard deviations)

\begin{tabular}{|c|c|c|c|c|c|c|c|c|}
\hline & \multicolumn{2}{|c|}{$\begin{array}{c}\text { Young adults } \\
(25-34 \text { years; } n 54)\end{array}$} & \multicolumn{2}{|c|}{$\begin{array}{c}\text { Young elderly } \\
\text { (65-85 years; } n 44)\end{array}$} & \multicolumn{2}{|c|}{$\begin{array}{c}\text { Old elderly } \\
\text { (>90 years; } n \text { 25) }\end{array}$} & \multicolumn{2}{|c|}{$\begin{array}{l}\text { Frail young elderly } \\
\text { (70-85 years; } n 50)\end{array}$} \\
\hline & Mean & SD & Mean & SD & Mean & SD & Mean & SD \\
\hline Age (years) & $28 \cdot 7$ & $3 \cdot 1$ & $79 \cdot 8^{\star \star \star}$ & $5 \cdot 1$ & $94 \cdot 3^{\star \star \star}$ & $3 \cdot 4$ & $79 \cdot 6^{\star \star \star}$ & $6 \cdot 2$ \\
\hline Albumin $(g / l)$ & $43 \cdot 5$ & $2 \cdot 8$ & $42 \cdot 4$ & $3 \cdot 9$ & $41 \cdot 4$ & $3 \cdot 8$ & $37 \cdot 1^{\star *} \dagger$ & 3.6 \\
\hline C-reactive protein (mg/l) & \multicolumn{2}{|c|}{$<6$} & \multicolumn{2}{|c|}{$<6$} & \multicolumn{2}{|c|}{$<6$} & $13 \cdot 4^{\star \star} \dagger$ & $10 \cdot 2$ \\
\hline \multicolumn{9}{|l|}{$\begin{array}{l}\text { Lymphocyte proliferation } \\
\text { with PHAp }\left(1 \mu \mathrm{g} / 10^{6} \text { cells }\right) \text { : }\end{array}$} \\
\hline$\left[{ }^{3} \mathrm{H}\right]$ thymidine $\left(\mathrm{cpm} / 10^{3}\right.$ cells $)$ & 144 & 47 & 121 & 36 & $78 \cdot 0^{\star \star}$ & 31 & $71^{* * *} \dagger \dagger$ & 35 \\
\hline Percentage CD25 + cells at $72 \mathrm{~h}$ & $65 \cdot 3$ & $6 \cdot 8$ & $58 \cdot 9$ & $7 \cdot 4$ & $45 \cdot 0^{\star *} \dagger$ & $9 \cdot 1$ & $41 \cdot 2 \dagger \dagger$ & $11 \cdot 4$ \\
\hline \multicolumn{9}{|l|}{ In vitro cytokine release after $22-24 \mathrm{~h}$} \\
\hline IL-2 (ng/ml) & $2 \cdot 09$ & 0.33 & $1 \cdot 83$ & 0.39 & $1 \cdot 29^{* * *} \dagger$ & 0.49 & $1 \cdot 16^{\star \star \star} \dagger$ & 0.42 \\
\hline IL-6 (ng/ml) & 1.38 & $0 \cdot 15$ & $1 \cdot 74^{*}$ & 0.23 & $1 \cdot 92^{\star \star \star}$ & 0.35 & $1 \cdot 41$ & 0.41 \\
\hline
\end{tabular}

cpm, counts per min.

Mean values were significantly different from those of the healthy young adults: ${ }^{\star} P<0.05,{ }^{\star \star} P<0 \cdot 01,{ }^{\star \star \star} P<0.001$

Mean values were significantly different from those of the healthy young elderly: $+P<0.05,+\dagger P<0.01$.

†Healthy young adults and elderly of different ages and health status were selected according to the criteria for the SENIEUR protocol of Ligthart et al. (1984) with the additional criteria of Lesourd \& Mazari (1999).

the immune system is particularly sensitive to undernutrition (Chandra, 1994; Lesourd, 1995, 1997; Bell \& High, 1997). Undernutrition is a common situation in elderly populations, not only major undernutrition such as protein-energy malnutrition (PEM; Lesourd et al. 1996; Bell \& High, 1997), but also micronutrient deficits (Tucker, 1995; Lesourd et al. 1998), which are far more common than PEM, even in apparently healthy elderly individuals.

The aim of the present review is to describe the influence of nutrition on immune responses in elderly individuals. Three different aspects of immune ageing will be described. The first is 'primary immune ageing', which can be observed in healthy elderly individuals carefully selected for having no nutritional deficit. This type of immune ageing corresponds to the now well-recognized 'successful ageing'. The second is the influence of micronutrient deficit on the immune responses of apparently healthy elderly individuals, termed 'secondary immune ageing'. This type of immune ageing is common in elderly populations and can therefore be termed 'common ageing'. The third is the immune responses that are observed in PEM in the elderly, i.e. 'tertiary immune ageing', which becomes increasingly common with advancing age and is certainly of great importance in elderly populations. This type of immune ageing is observed in diseased individuals and may therefore be termed 'pathological ageing'.

The present review attempts to provide a comprehensive overview of nutritional factors that influence immune ageing. Possible action to counteract common and pathological immune ageing will be suggested, as well as guidelines on measures to slow down immune ageing and extend the lifespan.

\section{Primary immune ageing: successful ageing}

In 1984 the EU Concerted Action Programme on Ageing (EURAGE) defined, for the first time, specific criteria for participants in studies of immune ageing. The SENIEUR protocol (Ligthart et al. 1984) was defined to better characterize criteria of healthiness. In 1988 a nutritional criterion was added, such that only subjects who did not have PEM (serum albumin $>35 \mathrm{~g} / \mathrm{l}$ ) would be eligible. As micronutrient deficits may influence the immune responses of elderly subjects, new criteria relating to micronutrient levels were subsequently added (Lesourd \& Mazari, 1999). Currently, elderly subjects who fulfil the SENIEUR criteria should have a serum albumin level of $\geq 39 \mathrm{~g} / \mathrm{l}$ and no deficit in $\mathrm{Zn}, \mathrm{Se}$, folic acid and vitamins $\mathrm{C}, \mathrm{E}, \mathrm{B}_{6}$ and $\mathrm{B}_{12}$ (all micronutrient known to influence immune responses) and, in addition, no major acute-phase response (serum C-reactive protein level of $<30 \mathrm{mg} / \mathrm{l}$ ).

When CMI responses were quantified in elderly (80 years old) individuals who met all the protocol criteria it was shown for the first time that lymphocyte proliferation and IL-2 release are comparable with those of young (20-30 years old) adults (Lesourd \& Meaume, 1994). This finding has been confirmed in subsequent studies (Mazari \& Lesourd, 1998; Lesourd \& Mazari, 1999; Ahluwalia et al. 2001). Age-related changes in CMI are mostly characterized by T-cell subpopulation changes: decreases in CD3 + T-cells, partly replaced by an increase in the CD2 + CD3 - T-cell subset; a switch from CD45RA+ (naïve cells) to CD45RO + (memory cells); a switch from T-helper (Th) 1 cells to Th2 subsets. These T-cell subset changes have little effect on T-cell functions (Table 1; Lesourd \& Meaume, 1994; Lesourd et al. 1994; Mazari \& Lesourd, 1998; Lesourd \& Mazari, 1999; Ahluwalia et al. 2001). Some of these changes, such as the naïve-memory switch, occur early in life, mainly before 30 years of age, but continue to occur at a lower rate throughout life (Cossarizza et al. 1992). However, although peak lymphocyte proliferation is comparable for young and elderly individuals, peak responses are reached later in elderly individuals (3-4d) when compared with their young counterparts (2-3 d; Mazari \& Lesourd, 1998; Lesourd 
\& Mazari, 1999). Decreased T-cell function is observed only in the very old healthy elderly ( $>90$ years old), who require very careful selection for criteria of healthiness (Table 1). Thus, in healthy individuals the decline in CMI occurs far later than has been previously reported. Changes in immune response are related either to changes in the body that are associated with ageing (i.e. the decline in thymus function that occurs after puberty, which is associated with $\mathrm{CD} 3+$ decline), or to antigenic stress that occurs during the lifespan for the naïve-memory and Th1-Th2 switches (Lesourd \& Mazari, 1999; Ahluwalia, 2004). The Th1-Th2 age-related switch may be of great importance. Indeed, Th1 responses induce activation of CD8 + cytotoxic T-cells and those of Th2 induce B-cells to secrete Ig. Cytotoxic T-cell numbers and function decline with age (Mbawuike et al. 1997) and this decline is probably of major importance in CMI function in vivo, since cytotoxic T-cells represent a very effective mechanism for killing infected body cells. The decrease in this population may explain the age-related increase in susceptibility to infection, even though the replication rate of $\mathrm{T}$-cells is apparently 'normal'. The increase in Th2 function may explain why Ig levels do not decline with age (Moulias et al. 1995).

Similar changes have been reported for humoral immunity (B-cell function). Ageing induces a switch from CD5- B-cells, which produce a specific antibody to foreign antigens, to CD5 + B-cells, which secrete autoantibodies (Weksler, 1995). Other reports have shown that antibody affinity declines with age (Muller et al. 1986) and autoantibodies increase with age (Arreaza et al. 1993). Thus, even though antibody production is only slightly reduced in elderly individuals, the specificity and affinity of the antibody produced is reduced, leading to lessadapted antibody responses.

Non-specific immunity (macrophage and polymorphonuclear functions) seems to be preserved or even enhanced with ageing. IL-1 production is sustained in human subjects (Nafziger et al. 1993), while IL-6 production is actually increased (Ershler et al. 1993; Lesourd, 2004). This situation represents a dysequilibrium in the immune response of the elderly individual; the functions of accessory cells that induce immune response are maintained and the functions of T-cells, which are the active cells, are partially decreased. Thus, in order to produce an appropriate immune response after an antigenic challenge, macrophages must secrete more cytokines to enhance partially-defective lymphocytes, which leads to greater or long-lasting proinflammatory responses in elderly individuals. Indeed, stress-induced metabolic effects are prolonged in old animals compared with young animals (Sapolski et al. 1983). As proinflammatory cytokines have numerous metabolic activities, such as increases in muscle protein breakdown, the metabolic effects of acute-phase responses are increased in elderly individuals. These catabolized muscle proteins are not fully replaced after recovery in elderly individuals because protein synthesis rates are reduced (Welle et al. 1993; Yarasheski et al. 1993). Thus, any antigenic challenge induces a reduction in muscle protein in elderly individuals, leading to a more frail state. In addition, monocytes from elderly individuals produce more prostaglandin $\mathrm{E}_{2}$, a suppressive factor to lymphocytes (Hayek et al. 1997). Furthermore, lymphocytes from elderly individuals are more sensitive to prostaglandin $\mathrm{E}_{2}$ activity (Goodwin, 1982). Thus, any monocyte activation, i.e. acute-phase response, induces partial decreases in lymphocyte function, explaining the need for greater secretion of proinflammatory cytokines to stimulate lymphocytes during an antigenic challenge in the elderly. This requirement for higher levels of proinflammatory cytokines may explain the higher IL-6 levels observed in the elderly individuals, even when they are apparently very healthy (Ershler et al. 1993).

\section{Secondary immune ageing: common ageing}

Immune responses are influenced by micronutrient deficits, which are quite common in the elderly population. Indeed, one-third to half the 75-year-old self-sufficient home-living elderly population have decreased intakes in at least one micronutrient (Lesourd et al. 1998). Since many micronutrients influence immune responses, this decreased micronutrient intake may induce decreases in CMI responses.

In the first controlled supplementation study conducted in an elderly population with a micronutrient deficit (Talbott et al. 1987) the subjects were given a physiological dose of pyridoxine $(500 \mathrm{mg})$, which it was shown may enhance lymphocyte proliferation, but only in subjects with low serum pyridoxal $5^{\prime}$-phosphate levels. Similar observations have been documented for patients with $\mathrm{Zn}$ deficiency who received physiological doses of $\mathrm{Zn}$ (Boubaika et al. 1993; Prasad et al. 1993). Prasad et al. (1993) have reported that $\mathrm{Zn}$ supplementation enhances serum thymulin and IL-1 secretions from monocytes; an effect that is related to increased plasma $\mathrm{Zn}$ levels and polymorphonuclear $\mathrm{Zn}$ contents. Furthermore, $\mathrm{Zn}$ supplementation is also associated with decreased serum $\mathrm{Cu}$, which may explain why there is no effect on lymphocyte function. It has also been shown that $\mathrm{Zn}$ supplementation may be detrimental (Bogden et al. 1990).

A similar study has been conducted in which a folic acid supplement at physiological doses $(2 \times$ RDA) was given to apparently healthy elderly subjects carefully selected for the absence of PEM (BMI $>23 \mathrm{~kg} / \mathrm{m}^{2}$, albumin $>38 \mathrm{~g} / \mathrm{l}$; Lesourd, 2004). The selected subjects did not have a folic acid deficit, only low erythrocyte folic acid contents that were within the normal range $(200-780 \mu \mathrm{g} / \mathrm{l})$ but in the lower part of this range $(200-450 \mu \mathrm{g} / \mathrm{l})$. In the folic acidsupplemented groups lymphocyte proliferation and IL-2 release were enhanced (Table 2) and were related to increased erythrocyte folic acid. It is now well-proven that some micronutrient deficits may be associated with decreased immune responses in 'apparently' healthy elderly and that correction of such deficits enhances immune responses (Lesourd, 1995; Lesourd et al. 1998). Thus, some of the reported age-related decreases in CMI responses may be a result of immune ageing or decreased micronutrient levels. The fact that immune responses can be enhanced in elderly individuals who do not have a folic acid deficit but have low erythrocyte folate levels indicates 
Table 2. Functions of peripheral blood lymphocytes, stimulated in vitro with purified phytohaemagglutinin (PHAp), in apparently healthy elderly $\ddagger$ with or without folic acid supplementation

(Values are means and standard deviations)

\begin{tabular}{|c|c|c|c|c|c|c|c|c|}
\hline & \multicolumn{2}{|c|}{$\begin{array}{l}\text { Serum folates } \\
(\mu \mathrm{g} / \mathrm{l})\end{array}$} & \multicolumn{2}{|c|}{$\begin{array}{c}\text { IL-2 } \\
(\mathrm{ng} / \mathrm{ml})\end{array}$} & \multicolumn{2}{|c|}{$\begin{array}{l}{\left[{ }^{3} \mathrm{H}\right] \text { thymidine (counts per }} \\
\text { min per } 10^{3} \text { cells) }\end{array}$} & \multicolumn{2}{|c|}{$\begin{array}{l}\text { Percentage of CD25 + cells } \\
\text { after } 48 \mathrm{~h} \text { of culture }\end{array}$} \\
\hline & Mean & $\mathrm{SD}$ & Mean & $\mathrm{SD}$ & Mean & $\mathrm{SD}$ & Mean & $\mathrm{SD}$ \\
\hline \multicolumn{9}{|l|}{ Placebo group ( $n$ 26) } \\
\hline Before supplementation & 332 & 214 & $1 \cdot 12$ & 0.31 & 64 & 33 & $39 \cdot 7$ & $10 \cdot 9$ \\
\hline After supplementation & $386^{\star \star}$ & 241 & $1 \cdot 19^{*}$ & 0.26 & $59^{\star *}$ & 23 & $37 \cdot 8^{\star *}$ & $12 \cdot 4$ \\
\hline \multicolumn{9}{|l|}{ Treated group ( $n$ 26) } \\
\hline After supplementation & 743†† & 236 & $1 \cdot 54 † \dagger$ & 0.36 & 99†† & $21 \cdot 3$ & $67 \cdot 2 \dagger \dagger$ & $10 \cdot 1$ \\
\hline
\end{tabular}

Mean values were significantly different within groups before and after supplementation: ${ }^{\star} P<0.05,{ }^{\star \star} P<0.01$.

Mean values were significantly different between groups before and after supplementation: $\uparrow P<0.05,+\dagger P<0 \cdot 01$.

$\ddagger$ Apparently healthy elderly, aged 78.4 (SD $5 \cdot 6$ ) years, carefully selected for the absence of a folic acid deficit (serum haematic folates $>200 \mu \mathrm{g} / \mathrm{l}$ ) were treated with $800 \mathrm{mg}$ folic $\mathrm{acid} / \mathrm{d}$ for $20 \mathrm{~d}$.

that micronutrients may have an important effect on immune responses in elderly individuals. Furthermore, Meydani et al. (1990, 1997) have shown that vitamin E supplements enhance lymphocyte proliferation, delayedtype hypersensitivity and IL-2 release in elderly individuals with 'normal' vitamin E levels. These effects were shown to be associated with decreased free radical production (lipoperoxidation) and were achieved using pharmacological doses $(5-10 \times \mathrm{RDA})$ of vitamin $\mathrm{E}$ provided as a supplement.

Such findings raise three major questions: (1) are decreases in CMI responses a result only of insufficient micronutrient levels in elderly individuals; (2) are the micronutrient requirements of elderly individuals different from those of their younger counterparts, and if so, are the current RDA appropriate for them; (3) are these different requirements associated with increased free radical production in elderly individuals. It would appear that free radical production is an important factor in the immune responses of elderly subjects and that the requirements are different (Meydani et al. 1995). Indeed, in the most recent French RDA (Martin, 2000) those for Se, folates, vitamin $\mathrm{C}$ and mainly for vitamin $\mathrm{E}$ have been increased for elderly individuals.

Single supplements and multi-supplements that combine antioxidants or other micronutrients may influence immune responses in elderly subjects. A combination of antioxidant vitamins has been reported to enhance CMI responses after $28 \mathrm{~d}$ in hospitalized patients (Penn et al. 1991). Similarly, the MIN.VIT.AOX study (Galan et al. 1997), which used combinations of physiological doses of antioxidant vitamins and/or trace elements, has shown that non-specific immunity (IL-1 production) is enhanced in the institutionalized elderly. This effect has been reported to be associated only with the antioxidant vitamin supplements and to be correlated with decreased free radical production (Girodon et al. 1997). In contrast, these supplements may enhance antibody titres after treatment with an influenza vaccine, but this effect is only correlated with the antioxidant trace element supplement (Girodon et al. 1999). This latter effect has also been shown to be associated with a reduced incidence of infection over a 2 -year study period (Girodon et al. 1999). Other studies that have used commercial 'cocktails' of various combinations of multivitamins and multiminerals at physiological doses $(0 \cdot 3-1 \times$ RDA $)$ have also shown that such supplements may enhance immune responses in elderly subjects (Chandra, 1993, 2002; Bogden et al. 1994; Pike \& Chandra, 1995). These effects have been observed in both institutionalized (Penn et al. 1991; Girodon et al. 1997, 1999) and self-sufficient home-living elderly subjects (Chandra, 1993, 2002; Bogden et al. 1994; Pike \& Chandra, 1995; Lesourd, 2004). Three studies have also shown that such multivitamin-multimineral supplements may reduce the period of infection (d) in supplemented individuals over 1 year (Chandra, 1993, 2002; Girodon et al. 1999). This effect is associated with enhanced CMI responses (numbers of $\mathrm{CD} 3+$ cells, lymphocyte proliferation and IL-2 release) and is correlated with enhanced blood levels of vitamins and trace elements (Chandra, 1993), but the clinical effect is not observed when the same supplement is used for a shorter period (Pike \& Chandra, 1995).

All these reports confirm that immune responses may be enhanced in elderly individuals by the use of micronutrient supplements. This outcome is associated with correction of micronutrient deficits in most cases but has also been observed, in a few studies, in individuals with 'normal' micronutrient levels (Meydani et al. 1990, 1997). The effect has also been found to be associated with clinical efficacy (i.e. a reduction in infection rate or length) in three of the studies (Chandra, 1993, 2002; Girodon et al. 1999) and with reduction in the consequences of free radicals in other studies (Meydani et al. 1990, 1995, 1997; Galan et al. 1997; Girodon et al. 1997), indicating that part of the effect is associated with the antioxidant action of the micronutrients used.

\section{Tertiary immune ageing: pathological ageing related to undernutrition}

Major undernutrition, PEM, is a common disease in elderly populations. It has been reported that PEM is present in $2-4 \%$ of home-living self-sufficient elderly subjects (Lesourd, 1994) and in $\leq 50 \%$ of institutionalized elderly subjects (Alix et al. 1992). In home-living subjects PEM is 


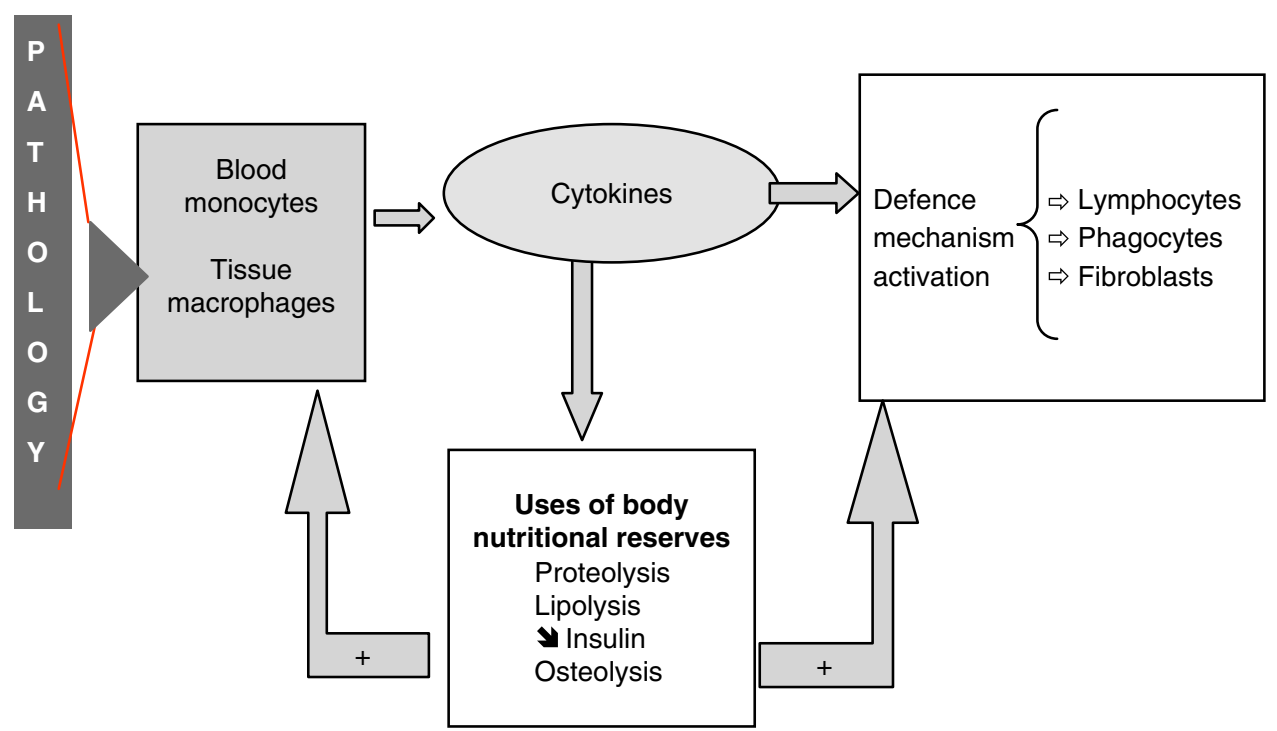

Fig. 1. Nutrition and disease. The body's response to stress and the relationship with body nutrient reserves. +, Body reserves are used to enhance defence mechanisms and macrophage metabolism; $\mathbf{y}$, insulin secretion decreases.

Table 3. Nutritional impact of disease in elderly subjects

Low nutritional reserves leading to osteoporosis and sarcopenia Metabolic changes lead to incomplete replacement of the catabolized muscle

Macrophage-lymphocyte dysequilibrium leads to long-lasting acute-phase responses

often associated with chronically low intakes, while in nursing homes and hospitals PEM is often associated with on-going diseases (Lesourd, 1994). Immunodeficiency is strongly correlated with the severity of PEM (Lesourd, 1999; Lesourd et al. 2002) and is associated with increased complication rates (Sullivan et al. 1990; Sullivan \& Walls, 1995), mainly infections (Sullivan et al. 1990; Sullivan \& Walls, 1995), and with death rates (Cederholm et al. 1995; Sullivan et al. 1995). It is now well-known that undernutrition leads to a more frail state in the elderly (Lesourd, 1996, 2001). The ability of refeeding therapy to restore immune responses depends on the presence or absence of acute-phase responses. Refeeding therapy has a rapid effect in patients with low acute-phase responses, but when acute-phase responses are more intense (i.e. C-reactive protein $>30 \mathrm{mg} / \mathrm{l}$ ) such therapies need to be given for a longer period to be effective (Lesourd \& Mazari, 1997; Lesourd, 1999). This finding confirms the interrelationship between nutritional status and immune responses in elderly patients.

The stress response is a key for nutritional efficacy in elderly patients. Whatever the cause of stress, the body reacts with acute-phase responses associated with proinflammatory cytokine release from monocyte-macrophages, i.e. IL-1, TNF, IL-6 (Fig. 1). The cytokines enhance cells acting on body defences and, in parallel, induce the use of nutritional reserves, which is particularly harmful in the elderly for several reasons (Table 3): (1) body reserves are already decreased in elderly individuals who exhibit osteoporosis and often sarcopenia; (2) acute-phase responses are long lasting in elderly animals and human subjects (Sapolski et al. 1983), so that more body reserves are used; (3) nutritional reserves are never fully replaced in elderly individuals during recovery, since protein anabolism is decreased (Welle et al. 1993; Yarasheski et al. 1993); (4) each acute-phase response in the elderly can therefore lead to lower nutritional reserves, mainly muscle protein reserves, which can increase frailty. In conclusion, in the elderly repeated bouts of disease can lead to a progressive loss of body reserves, a progressively lower nutritional status and increased frailty. In parallel, the lowered nutritional status induces lower immune responses, leading to increased susceptibility to disease complications such as infections, which in turn contributes to increased frailty. Thus, not only are decreased immune responses an important part of increased frailty in elderly individuals, but they are also partly responsible for increased frailty when a disease occurs.

\section{Conclusions}

Immune responses and nutritional status are closely interrelated in elderly individuals. Deficits of any nutrient (micronutrients and/or macronutrients) that affects the immune response induce decreased responses in elderly individuals. The decreased immune responses lead to increased susceptibility to disease, and disease induces further decreases in nutritional status and, as a consequence, in immune responses. Maintaining optimal nutritional status could therefore be a way of ensuring healthy ageing and extending the lifespan. Do elderly individuals have higher nutritional requirements than their younger counterparts? The question still remains to be answered, but the answer may be of importance for healthy ageing. 


\section{References}

Ahluwalia N (2004) Aging, nutrition and immune function. Journal of Nutrition, Health and Aging 8, 2-6.

Ahluwalia N, Mastro AM, Ball R, Miles MP, Rajondra R \& Handre G (2001) Cytokine production by stimulated mononuclear cells did not change with ageing in apparently healthy, well-nourished women. Mechanisms of Ageing and Development 122, 1269-1279.

Albright JF \& Albright JW (1984) Ageing alters the competence of the immune system to control parasitic infections. Iтmunology Letters 40, 279-285.

Alix E, Contans T, Lesourd B \& Ferry M (1992) Epidémiologie de la nutrition chez les personnes âgées (Epidemiology of undernutrition in old persons). Revue de Gériatrie 51, 749-758

Arreaza EE, Gibbons JJ, Sisking GW \& Weksler ME (1993) Lower antibody response to tetanus toxoid associated with higher auto-anti-idiotype antibody in old compared to young humans. Clinical and Experimental Immunology 92, 169-176.

Bell RA \& High KP (1997) Alteration of immune defense in the elderly: the role of nutrition. Infections in Medicine $\mathbf{1 4}$ 415-424.

Bogden JD, Bendich A, Kemp FW, Bruening KS, Shurnick JH, Denny TN, Baker H \& Louria DB (1994) Daily micronutrient supplements enhance delayed hypersensitivity skin test responses in older people. American Journal of Clinical Nutrition 60, 437-447.

Bogden JD, Oleske JM, Lavenhar MA, Munves EM, Kemp FW, Bruening KS, Holding KJ, Denny TN, Guarino MA \& Holland BK (1990) Effects of one year of supplementation with zinc and other micronutrients on cellular immunity in the elderly. Journal of the American College of Nutrition 9, 214-225.

Boubaika N, Flament C, Acher S, Chappuis Ph, Pian A, Fusselier M, Dardenne M \& Lemmonier D (1993) A physiological amount of zinc supplementation: effects on nutritional, lipid, and thymic status in an elderly population. American Journal of Clinical Nutrition 57, 566-572.

Cederholm T, Jagrën Ch \& Hellström K (1995) Outcome of protein-energy malnutrition in elderly medical patients. American Journal of Medicine 98, 67-74.

Chandra RK (1993) Effect of vitamin and trace-element supplementation: effects on nutritional, lipid and thymic status in an elderly population. American Journal of Clinical Nutrition 57, 566-572

Chandra RK (1994) Nutritional regulation of immune system and the extreme of life: in infants and in the elderly. In Malnutrition, Determinants and Consequences, pp. 245-251 [P White, editor]. New York: Alan R. Liss.

Chandra RK (2002) Influence of multinutrient supplement on immune responses and infection-related illness in 50-65 year old individuals. Nutrition Research 20, 5-11.

Cossarizza A, Ortolani C, Paganelli R, Monti D, Barbieri D, Sansoni P, Fagiolo U, Forti E, Lonfei M \& Franceschi C (1992) Age-related imbalance of virgin (CD45RA+) and memory (CD45RO+) cells between CD4+ and CD8 + $\mathrm{T}$ lymphocytes in humans: study from newborns to centenarians. Journal of Immunological Research 4, 118-126.

Ershler WB, Sun WH, Binkley N, Cravenstein S, Volk MJ, Kamoske G, Kloop RG, Rocker EB, Daynes RA \& Weindruch $\mathrm{R}$ (1993) Interleukin-6 and aging: blood levels and mononuclear cell production increase with advancing age and in vitro production modifiable by dietary restriction. Lymphokine and Cytokine Research 12, 225-230.

Galan P, Preciozi P, Monget AL, Richard MJ, Arnaud J, Lesourd B, Girodon F, Alferoz MJ, Bourgeois C, Keller H \& Favier A (1997) Effect of trace element and/or vitamin supplementation on vitamin and mineral status, free radical metabolism and immunological markers in elderly long term-hospitalized subjects. Geriatric Network: MIN.VIT.AOX. International Journal of Vitamin and Nutrition Research 67, 450-460.

Girodon F, Blache D, Monget AL, Lombard M, Brunet-Lecomte P, Arnaud J, Richard MJ \& Galan P (1997) Effect of a twoyear supplementation with low doses of antioxidant vitamins and/or minerals in elderly subjects on levels of nutrients and antioxidant defense parameters. Journal of the American College of Nutrition 4, 357-365.

Girodon F, Galan P, Monget AL, Boiron-Ruault MC, BrunetLecomte P, Preciozi P, Arnaud J, Manuguerra JC, Hercberg S \& the MIN.VIT.AOX Geriatric Network (1999) Impact of trace-element and vitamin supplementation on immunity and infections in institutionalized elderly patients. A randomized controlled trial. Archives of Internal Medicine 159, 748-754.

Goodwin JS (1982) Changes in lymphocyte sensitivity to prostaglandin E2, histamine, hydrocortisone, and X-irradiation with age: studies in a healthy elderly population. Clinical Immunology and Immunopathology 25, 243-251.

Hayek GM, Mura C, Wu D, Beharka AA, Han SN, Paulson E, Hwang D \& Meydani S (1997) Enhanced expression of inducible cyclooxygenase with age in murine macrophages. Journal of Immunology 159, 2445-2451.

Lesourd B (1995) Protein undernutrition as the major cause of decreased immune function in the elderly: clinical and functional implications. Nutrition Reviews 53, 86-94.

Lesourd B (1999) Immune response during disease and recovery in the elderly. Proceedings of the Nutrition Society 58, 85-98.

Lesourd B, Decarli B \& Dirren H (1996) Longitudinal changes in iron and protein status of elderly Europeans. SENECA Investigators. European Journal of Clinical Nutrition 50, Suppl. 2, S16-S24.

Lesourd B \& Mazari L (1999) Nutrition and immunity in the elderly. Proceedings of the Nutrition Society 58, 685-695.

Lesourd B, Mazari L \& Ferry M (1998) The role of nutrition and immunity in the aged. Nutrition Reviews 56, S113-S135.

Lesourd B, Raynaud-Simon A \& Mazari L (2002) Nutrition and ageing of the immune system. In Nutrition and Immune Function, pp. 357-374 [PC Calder, CJ Field and HS Gill, editors]. Wallingford, Oxon: CABI.

Lesourd BM (1994) La malnutrition protéino-énergétique chez les sujets âgés (Protein-energy malnutrition in aged persons). Semaines des Hôpitaux de Paris 70, 957-963.

Lesourd BM (1996) Hypermetabolism: a frightening symptom that pushes elderly to enter a vicious circle. In Vitality, Mortality and Ageing. Ageing Series no. 5, pp. 363-376 [A Viidik and G Hofecker, editors]. Vienna, Austria: Facultas Universitäts Verlag.

Lesourd BM (1997) Nutrition and immunity in the elderly: modification of immune responses with nutritional treatments. American Journal of Clinical Nutrition 66, 478S-488S.

Lesourd BM (2001) Undernutrition: a factor of accelerated immune aging in healthy and diseased aged persons. In Handbook of Nutrition and the Aged, 3rd ed., pp. 145-158 [RR Watson, editor]. New York: CRC Press.

Lesourd BM (2004) Nutrition: a major factor influencing immunity in the elderly. Journal of Nutrition, Health and Aging $\mathbf{8}$, $28-37$.

Lesourd BM, Laisney C, Salvatore R, Meaume S \& Moulias R (1994) Decreased maturation of T-cell populations in healthy elderly: influence of nutritional factors on the appearance of double negative CD4- CD8- CD2+ cells. Archives of Gerontology and Geriatrics 4, Suppl., 139-154.

Lesourd BM \& Mazari L (1997) Immune responses during recovery from protein-energy malnutrition. Clinical Nutrition 16, Suppl. 1, 37-46. 
Lesourd BM \& Meaume S (1994) Cell mediated immunity changes in ageing, relative importance of cell subpopulation switches and of nutritional factors. Immunology Letters $\mathbf{4 0}$, 235-242.

Ligthart GJ, Corberand JX, Fournier C, Galanaud P, Hijmans W, Kennes B, Muller-Hermelink HK \& Steinmann GG (1984) Admission criteria for immunogerontological studies in man: the SENIEUR protocol. Mechanisms of Ageing and Development 28, 47-55.

Martin A (2000) Apports Nutritionnels Conseillés pour la Population Française (RDA for the French Population). Paris: Tec \& Doc.

Mazari L \& Lesourd B (1998) Nutritional influences on immune response in healthy aged persons. Mechanisms of Ageing and Development 104, 25-40.

Mbawuike IN, Acuna CL, Walz KC, Atmar RL, Greenberg SB \& Couch RB (1997) Cytokines and impaired CD8+ CTL activity among elderly persons and the enhancing effect of IL-12. Mechanisms of Ageing and Development 94, 25-39.

Meydani SN, Barklund MP, Lui S, Meydani M \& Miller RA (1990) Vitamin E supplementation enhances cell-mediated immunity in healthy elderly. American Journal of Clinical Nutrition 52, 557-563.

Meydani SN, Meydani M, Blumberg JB, Lekal S, Siber G, Loszewsji R, Thompson C, Pedrosa C, Diamond RD \& Stollar BD (1997) Vitamin E supplementation and in vivo immune responses in healthy elderly subjects. Journal of the American Medical Association 277, 1380-1386.

Meydani SN, Wu D, Santos MS \& Hayek MG (1995) Antioxidants and immune response in aged persons: overview of the present evidence. American Journal of Clinical Nutrition 62, Suppl., 1462S-1476S.

Miller RA (1992) Aging and immune function. Review of Immunology 124, 890-904.

Moulias R, Devillechabrolle A, Lesourd B, Proust J, Marescot MR, Doumerc S, Favre-Berrone M, Congy F \& Wang A (1995) Respective roles of immune and nutritional factors in the priming of the immune responses in the elderly. Mechanisms of Ageing and Development 31, 123-137.

Muller S, Chang HC, Ward MM, Huang JH \& Kölher H (1986) Idiotype shifts. In Aging and the Immune Responses: Cellular and Humoral Aspects, pp. 309-327 [EA Goidl, editor]. New York: Marcel Dekker.

Nafziger J, Bessege JP, Guillosson JJ, Damais C \& Lesourd B (1993) Decreased capacity of IL1 production by monocytes of infected elderly patients. Ageing; Immunology and Infectious Disease 4, 425-434.

Pawelec G, Remarque E, Barnette Y \& Solana R (1997) T cells and aging. Frontiers in Bioscience 3, 59-99.

Penn ND, Purkins L, Kelleher J, Heatley RV, Mascle-Taylor BH \& Belfield PW (1991) The effect of dietary supplementation with vitamins $\mathrm{A}, \mathrm{C}$ and $\mathrm{E}$ on cell-mediated immune function in elderly long-stay patients: a randomized controlled trial. Age \& Ageing 20, 169-174.

Pike J \& Chandra RK (1995) Effect of vitamin and trace element supplementation on immune indices in healthy elderly. International Journal of Vitamin and Nutrition Research $\mathbf{6 5}$, 117-121.

Prasad AS, Fitzgerald JT, Hess JW, Kaplan J, Pelen F \& Dardenne M (1993) Zinc deficiency in elderly patients. Nutrition 9, 218-224.

Sapolski RM, Krey LC \& McEwen BF (1983) The adrenocortical stress response in the aged male rats: impairment of recovery after stress. Experimental Gerontology 18, 284-301.

Sullivan DH, Patch GA, Walls RC \& Lipschitz DA (1990) Impact of nutrition status on morbidity and mortality in a select population of geriatric rehabilitation patients. American Journal of Clinical Nutrition 51, 749-758.

Sullivan DH \& Walls RC (1995) The risk of life-threatening complications in a select population of geriatric patients: the impact of nutritional status. Journal of the College of Nutrition 14, 29-36.

Sullivan DH, Walls RC \& Bopp MM (1995) Protein-energy undernutrition and the risk of mortality within one-year of hospital discharge: a follow-up study. Journal of the American Geriatrics Society 43, 507-512.

Talbott MC, Miller LT \& Kerkvliet NJ (1987) Pyridoxine supplementation: effect on lymphocyte responses in elderly persons. American Journal of Clinical Nutrition 46, 659-663.

Tucker K (1995) Micronutrient status and ageing. Nutrition Reviews 53, S9-S15.

Weksler ME (1995) Immune senescence: deficiency or dysregulation. Nutrition Reviews 53, S3-S7.

Welle S, Thornton C. \& Jozefowicz R (1993) Myofibrillar protein synthesis in young and old men. American Journal of Physiology 264, E693-E698.

Yarasheski KE, Zachwieja JJ \& Bier DM (1993) Acute effects of resistance exercise on muscle protein synthesis rate in young and elderly men and women. American Journal of Physiology 265, E210-E214. 